\title{
Spawning and Nesting Behaviour of Tachypleus gigas along the East Coast of Peninsular Malaysia
}

\author{
K. Zaleha \\ Faculty of Fisheries and Aqua-Industry, University Malaysia Terengganu \\ 21030 Kuala Terengganu, Terengganu, Malaysia \\ E-mail: zaleha@umt.edu.my \\ B. Akbar John \\ Institute of Oceanography and Maritime studies (INOCEM) \\ Kulliyyah of Science, International Islamic University Malaysia \\ Jalan Sultan Ahmad Shah, Bandar Indera Mahkota \\ Kuantan Pahang 25200, Malaysia \\ E-mail: akbarjohn50@gmail.com

\section{H. Erni Atika} \\ Faculty of Maritime Studies and Marine Science, University Malaysia Terengganu \\ 21030 Kuala Terengganu, Terengganu, Malaysia \\ B. Y. Kamaruzzaman \& K. C. A. Jalal \\ Institute of Oceanography and Maritime studies (INOCEM) \\ Kulliyyah of Science, International Islamic University Malaysia \\ Jalan Sultan Ahmad Shah, Bandar Indera Mahkota \\ Kuantan Pahang 25200, Malaysia
}

Received: February 14, $2012 \quad$ Accepted: March 2, $2012 \quad$ Published: April 1, 2012

doi:10.5539/ijb.v4n2p102

URL: http://dx.doi.org/10.5539/ijb.v4n2p102

\begin{abstract}
Present study was aimed to address the spawning and nesting behaviour of Malaysian horseshoe crab (Tachypleus gigas) in observed nesting grounds of East coast of Peninsular Malaysia during monsoonal period. Field sampling was carried out in every full and new moon days between September and December 2009 in Balok (Lat3 ${ }^{\circ} 56.194^{\prime}$ N, Long10322.608' E) and Pekan (Lat3 36.181' N, Long10323.946' E) nesting grounds. A total of 26 nests were found throughout the sampling period (Balok $=4$ nests $[\sim 15 \%]$; Pekan $=22$ nests $[\sim 85 \%])$ with higher percentage nesting was noted in November $(\mathrm{N}=11$ nests $[\sim 50 \%])$ in Pekan. No nests were found in Balok station in all sampling months except during September (4 nests). It was also noted that the horseshoe crab preferred nesting during full moon time compared to new moon period. Mean depth $\times$ width of the T.gigas nests were $19.96 \pm 5.6 \times 10.72 \pm 2.1 \mathrm{~cm}$. Number of eggs and larval counting in each nest were also recorded together with hydrographic and sedimentological parameters of the nesting grounds. This study clearly showed negative influence of monsoonal cycle on the nest preference and spawning behaviour of T.gigas. Long term monitoring studies would enable us to understand the number of shore reaching horseshoe crabs which is an essential source for the wild population.
\end{abstract}

Keywords: Nesting ground, Balok and Pekan, Horseshoe crab, Population ecology 


\section{Introduction}

An important biomedical application to detect/quantify bacterial endotoxin (lipopolysaccharide) using a specialized cell compound from horseshoe crab blood lead to greater exploitation of their natural population worldwide (John et al., 2011). At present, horseshoe crabs are the sole source of those compounds technically known as Limulus/Tachypleus Amebocyte Lysate (LAL/TAL) which contributes billion dollar (\$) profit annually. Number of studies were attempted to explore their ecological status and biological applications of horseshoe crab especially on American species (Limulus polyphemus) (ASMFC, 1998; Shuster et al., 2003; Botton \& Shuster, 2004; Ehlinger and Tankersley, 2004; Shuster, 2004; Tanacredi et al., 2009; Botton and Itow, 2009) and Asian conspecifics (Chiu et al., 1999; Chiu and Morton, 2003; John et al., 2010; Zaleha et al., 2010; Akbar John et al., 2011a \& b; John et al., 2011; 2012a \& b; Kamaruzzaman et al., 2011a \& b). However, the ecophysiological status of Malaysian horseshoe crab (Tachypleus gigas) is still limited (Akbar John et al., 2011 and 2012a).

It is well documented that the nesting and spawning behaviour of horseshoe crab is directly related to the nature of nesting grounds (Botton et al., 1988). Wyse, (1971) has found the chemoreceptor in horseshoe crab tail helps them in differentiating the nursery/nesting beaches and thus Botton et al., (1988) concluded that horseshoe crabs are capable of discriminating between beaches of different geochemical regimes. The reproductive behaviour of horseshoe crabs is observed to be periodic and well synchronized with the tides (Gretchen and Richard 2006). During high tide, horseshoe crabs migrates towards the nesting beaches at every full and new moon days (especially at night time) to spawn. During this migration, the male crabs are tenaciously attached to the female opisthosoma using modified, claw-like pedipalps (Brockmann and Penn, 1992). Female crabs dig nests in the swash zone to deposit their eggs in clusters which contains approximately 2000 eggs (Jackson et al., 2007). The development of nested eggs in to trilobite larvae is greatly influenced by external environmental conditions.

In Malaysia, the nesting of horseshoe crab observed throughout the year especially in Balok and Pekan (East coast of Peninsular Malaysia) with the peak mating season during warmer months June and July (Kamaruzzaman et al., 2010). Few recent studies on the ecophysiology of the horseshoe crab nesting grounds in Malaysia are discussed in literatures (John et al., 2011 \& 2012a). However, the detail on the nesting and spawning of T.gigas in Malaysian coastline is less explored. Present study was aimed to provide the spawning and nesting behaviour of Malaysian horseshoe crab (T.gigas) in the observed nesting grounds of East coast of Peninsular Malaysia and to provide the hydrological and sedimentological parameters of the selected nesting grounds.

\section{Materials and Methods}

\subsection{Sampling area and sampling design}

The sampling was carried out in every full and new moon days at two different stations Balok and Pekan (East coast of Peninsular Malaysia) which were observed to be the nesting grounds of horseshoe crabs (Zaleha et al., 2010) (Figure 1). Locations of nests were identified in both the nesting grounds between September 2009 and December 2009 (Monsoon season). The nests were excavated using the scope until the fertilized eggs and larvae observed, the diameter and depth of the nests were recorded using measuring tape. Number of fertilized eggs and developing larvae in each nest was counted and sediment samples were collected in replicates. The eggs and larvae were placed back in the nests and packed loosely with the surrounding sand. The number of old and new nests were also recorded based on the nest content. The nests which comprised of mixture of eggs, early trilobite and trilobite larvae were classified as the old nest while the nests contain only fertilized eggs were categorized as new nests. Total Organic Matter (TOM) and Particle Size Analysis were carried out using dry sieve method. Hydrological parameters such as surface water salinity, temperature and Dissolved Oxygen level were recorded in every full and new moon days using YSI multi probe Hanna HI 9828.

\subsection{Sediment characteristics analysis}

Dry sieving method was carried out to analyze the particle size of sediments. The sediments were left air-dried for a week and $100 \mathrm{~g}$ of samples was weighed for the coarse size analysis. The samples were transferred on a mechanical shaker using a several series of mesh opening for grade classification of particle size. The samples were allowed to stand for 15 minutes in mechanical shaker and the samples of each individual sieve were weighed (Incera et al., 2003). Sediment samples were graded and type of sediments was classified and sorted using standard method of Wentworth et al. (1992) and Briggs (1977). The following formulas were used to calculate mean sediment size and sediment sorting values;

Mean sediment size

$$
\text { Mean Sediment Size }\left(X \text { ø) }=\sum \mathrm{fm} / \mathrm{n}\right.
$$


where,

$$
\begin{aligned}
\text { 'f } & =\text { percentage weight of each grade of particle size } \\
\text { ' } \mathrm{m} ' \quad & =\text { median of each particle size in } \varnothing \\
\text { and } \quad \text { ' } \mathrm{n} \text { ' } & =\text { total number of samples in } 100 \text { where } \mathrm{f} \text { is in percentage form }
\end{aligned}
$$

Sediment sorting value was calculated using the following equation

$$
S d \emptyset=\sqrt{\sum f \frac{(m-x \emptyset)^{2}}{100}}
$$

where,

$$
\begin{aligned}
& \text { ' } m \text { ' }=\text { median of each particle size in } \varnothing \\
& \text { ' } \chi_{\varnothing} \text { ' }=\text { Mean sediment size }
\end{aligned}
$$

\subsection{Total organic matter (ash-free dry weight method)}

Lenore et al., (1999) method was adopted to determine Total Organic Matter. 50 grams of sediment was weighed and oven dried at $60^{\circ} \mathrm{C}$ for 24 hours. Total organic matter content was determined as the loss in weight of sediment, dried at $60^{\circ} \mathrm{C}$ to constant weight after combustion at $475^{\circ} \mathrm{C}$ for two hours.

\subsection{Data analysis}

Kruskall-wallis non-parametric test was used to determine the difference in horseshoe crab nest distribution between two beaches. Pearson correlation analysis was performed to check the influence of hydrographic and sedimentological parameters over the number of horseshoe crab nests and egg counts in both the sampling beaches. All statistical tests were performed using SPSS 17v.

\section{Results}

A total of 26 nests were found in Balok and Pekan nesting grounds during the monsoon period (Sep-Dec) comprising of 22 nests in Pekan (84.6\%) and 4 nests in Balok (15.39\%). Highest number of nests was found during November $(\mathrm{N}=11)$ followed by 7 nests in October in Pekan. No nests were observed in Balok station during the sampling months except in September with 4 nests during new-moon period. In general, highest number of nests was recorded in new-moon period compared to full moon. Distribution of old and new nests was recorded to be $42.31 \%$ and $57.69 \%$ respectively. Significant difference in the distribution of horseshoe crab nests were observed between two nursery grounds $(\mathrm{P}<0.01)$ while it was non-significant within a beach $(\mathrm{P}>0.05)$.

Number of fertilized eggs, early trilobite and hatched trilobite larvae in each nest varied from 0-331, 0-350 and 0-391 respectively in Pekan station. Nests in Balok consisted only of fertilized eggs $(\mathrm{N}=376-407)$ and no larvae was found during the study period. Highest number of eggs, were found in Balok nests $(\mathrm{N}=407)$ while the highest number of early trilobite $(\mathrm{N}=350)$ and trilobite $(\mathrm{N}=391)$ were observed in Pekan station. Tavhypleus gigas preferred to lay eggs at depth varied from 5 to $15 \mathrm{~cm}$ with mean depth of $10.73 \mathrm{~cm} \pm 2.13$ while the width varied between 8 and $28 \mathrm{~cm}$ (Table 1). The average distance between the nests with high and low tide points were $2.6 \pm 1.6 \mathrm{~m}$ and $9.46 \pm 3.19 \mathrm{~m}$ respectively.

\subsection{Hydrographic parameters}

Highest salinity was recorded during October $(25.5 \mathrm{ppt})$ in Pekan and September (22.3 ppt) in Balok while the lowest salinity was noted during November (1.62 ppt) in Pekan and October (0.66 ppt) in Balok. In general, surface water temperature was $>20^{\circ} \mathrm{C}$ in both the stations. Highest surface water temperature was noted during December $\left(32.6^{\circ} \mathrm{C}\right)$ in Pekan and September $\left(32.23^{\circ} \mathrm{C}\right)$ in Balok while the lowest temperature was noted during November in both the sampling stations with the values of $25.67^{\circ} \mathrm{C}$ and $27.66^{\circ} \mathrm{C}$ respectively. Throughout the sampling period, the dissolved oxygen level in the surface water was lower in both the stations varied between $3.23-4.63 \mathrm{mg} / \mathrm{l}$ in Pekan and 0.79-5.62 in Balok station (Table 2). Comparison of hydrographic parameters between two sampling sites showed no significant difference $(\mathrm{P}>0.05)$.

\subsection{Sediment characteristics}

Percentage of total organic content was higher in Balok station compared to Pekan. Significant difference in total organic content was noted between two sampling stations $(\mathrm{P}<0.001)$. Highest percentage of total organic matter (TOM) was recorded during December in Balok $(0.76 \%)$ while it was $0.5 \%$ in Pekan station during November. 
Lowest TOM was noted during September in both the stations with the percentage values of $0.04 \%$ and $0.3 \%$ in Pekan and Balok respectively.

Over all, mean sediment size varied between 0.38 to $0.8 \varnothing$ in Pekan and 1.86-2.57Ø in Balok while sediment sorting value varied from 0.82 to1.04Ø in Pekan and 0.46-1.1Ø in Balok station. Mean sediment grain size analysis showed the presence of coarser sand in Pekan and medium sand in Balok station during September-November. However, grain size analysis indicated the prevalance of very coarse sand and finer sand particles in Pekan and Balok beaches respectively. ANOVA test showed significant variations in mean sediment size between the beaches $(\mathrm{P}<0.001)$ while no significant variation in mean sediment size was observed between months. Sediment sorting values showed the nature of sand in both the beaches were of poorly sorted during September. During October and November, the nesting beaches constituted by moderately sorted sediments except in Balok station which consisted of poorly sorted sediment during October. No significant difference was noted in sediment sorting values between sampling stations during different months $(\mathrm{P}>0.05)$ (Table 3$)$.

\subsection{Pearson correlation analysis}

Pearson correlation analysis showed the significant influence of dissolved oxygen level and total organic content on the distribution of eggs count and number of horseshoe crab nests in both the sampling stations $(\mathrm{P}<0.05)$. Interestingly, both the parameters were positively correlated with nesting and egg counts. However, other parameters had no significant influence on the eggs count and nest numbers along the nesting beaches (Table 4).

\section{Discussion}

Present study revealed less preference of horseshoe crabs in nesting eggs during monsoon period. Early studies on American horseshoe crab showed Limulus polyphemus prefers to nest during the warmer months from May to August with a peak in June (Sokoloff, 1975). Recent studies along the Pahang coast by Akbar John (2011a \& 2012) proved that T.gigas also tend to prefer warmer months for nesting with the peak mating season on June-August. Throughout the sampling period, the number of eggs, larval stages in each nests showed significant number variations within and among different months. Similar observation was made by number of researchers (Cohen and Brockmann, 1983; Brockmann, 1996) who claimed that there is a significant variation in the quantities of eggs being laid by females during different tides across the mating seasons.

Nests in Pekan station had mix proportion of eggs, early trilobite and hatched trilobite larvae which might be due to the combined influence of various hydrological parameters that play a key role in development of nested eggs (Mikkelsen, 1988). Newly laid eggs are sticky and adhere to each other in a form of clumped balls which eventually hatch out as trilobite larvae after 28 days and enter the surrounding water during high tide time (Penn and Brockmann, 1994). Among all the nest content, only a single nest consisted of blackened eggs which might probably be due to the increased hydrogen sulfide content. The finding of both old and new nests in the nursery beaches with no significant difference in numbers $(\mathrm{P}>0.05)$ could indicate the more frequent of horseshoe crab to land on Pekan shore than Balok.

Physicochemical parameters showed no significant difference within and among the sampling stations. The surface water temperature was observed to be $>20^{\circ} \mathrm{C}$ in both the station which is suitable for spawning activity of horseshoe crab (Atlantic States Marine Fisheries Commision 1998). Jegla and Costlow (1982) also stated that temperature also affects the rate of embryonic development and the duration of post-hatch intermolt stages, with the optimal temperature for development ranging from $25^{\circ} \mathrm{C}$ to $30^{\circ} \mathrm{C}$. Pearson correlation analysis showed no significant influence of salinity and $\mathrm{pH}$ on the number of eggs in the nesting grounds. This observation was well corresponded with in vitro studies on the salinity tolerance of conspecific species L.polyphemus (Shuster, 1982). In addition, Zaleha et al. (2011) found that when eggs were incubated at temperature of $26-29^{\circ} \mathrm{C}$, they could hatch optimally at a wide range of salinity which is between 25 to 35 ppt. In contrast to other environmental parameters, dissolved oxygen level showed strong correlation with the number of nests at both the stations ( $\mathrm{P}<$ 0.05). Chiu and Morton (2003) noted that high oxygen levels in water would help in creating well oxygenated micro habitat for developing eggs.

The present finding proves the success of egg hatching and survival of larval stages are not limited by major physicochemical parameters such as salinity, $\mathrm{pH}$ and dissolved oxygen level in the nesting grounds. Strong correlation was noted between total organic matter and number of eggs in nesting grounds. Lesser organic content in Balok could have promoted more nesting during September. Allochthonous inputs in the sheltered beach such as Balok comes from the fishing activity and domestic waste from the nearby fishing villages. This increases the organic content on the beach particularly during monsoon months of October to December due to high accumulation of sedimentary organic matter (Incera et al. 2003). 
Mean sediment size showed the presence of medium sand particles in Balok and coarse sand in Pekan. The horseshoe crab seems to prefer the coarse sand compared to medium sand in which the number of horseshoe crab nests was found much higher at Pekan compared to Balok. Ellingsen, (2002) showed that sediment grain size determines the drainage of a beach, which greatly affects the interstitial oxygen content. The Balok beach sediments were fine to medium sand grained, thus had poor drainage compared to Pekan sediments. Jackson et al. (2007) noted on the importance of grain size to determine the hatching and development of horseshoe crab larvae where beside pebble fraction, finer sediment may increase egg survival. Nevertheless, fine grained sediments in Balok while having greater surface areas for water retention, could promote microbial growth due to the heavy human activities in the area. This further depleted interstitial oxygen, increases hydrogen sulphide, and lowers redox levels. This might be the reasons why Balok is less preferred by horseshoe crab as compared to Pekan. Significant different of grain size at these two locations indicated that the location received different wave with Pekan site exposed to stronger current. This could also explain the higher and more stable dissolved oxygen concentration in Pekan than Balok which in turn could attract nesting behavior of horseshoe crab in the area. Stronger wave also promote inundating of eggs thus increase hatching success (Ehlinger and Tankersley, 2003).

\section{Conclusion}

A total of 26 nests were found throughout the sampling period in two nursery ground beaches constituting high preference of nesting in Pekan compared to Balok station during monsoon period. Hydrographic and sedimentological parameters had no significant influence on number of nests and egg counts in both the sampling beaches except dissolved oxygen level and TOC. The dwindling population size of horseshoe crab in Malaysian coast line in recent years might probably be due to various anthropogenic activities in the nesting beaches which eventually alter the nursery ground quality. Long term monitoring studies would enhance our understanding on horseshoe crab spawning and breeding behaviour at their nesting grounds.

\section{References}

Akbar John, B., Jalal, K. C. A., Zaleha, K., Armstrong, P., \& Kamaruzzaman, B. Y. (2011a). Effects of blood extraction on the mortality of Malaysian horseshoe crabs (Tachypleus gigas), Marine and Freshwater Behaviour and Physiology, 44(5), 321-327. http://dx.doi.org/10.1080/10236244.2011.642505

Akbar John, B., Kamaruzzaman, B. Y., Jalal, K. C. A., \& Zaleha, K. (2012a). Sediment Profiling of the Nesting Grounds of Horseshoe Crabs at East Peninsular Malaysia. International Journal of Biology, In press.

Akbar John, B., Kamaruzzaman, B. Y., Jalal, K. C. A., \& Zaleha, K. (2012b). TAL - A source of bacterial endotoxin detector in liquid biological samples. International Food Research Journal, 19(2), 423-425.

Akbar John, B., Kamaruzzaman, B. Y., Jalal, K. C. A., \& Zaleha, K. (2011b). Study on the Bionomics of Malaysian horseshoe crabs Tachypleus gigas. International Symposium on "Marine Ecosystems, Natural Products and their Bioactive Metabolites”. 25 - 27 October 2 011, Bogor - Indonesia. pp.137.

Akbar John, B., Kamaruzzaman, B. Y., Jalal. K. C. A., \& Zaleha, K. (2011c). Feeding ecology of mangrove horseshoe crab Carcinoscorpius rotundicauda (Latreille, 1802). International Fisheries symposium (IFS 2011). 3-5 October, 2011. Permai hotel, Kuala Terengganu, Terengganu, Malaysia. pp. 112-113.

Atlantic States Marine Fisheries Commission (ASMFC). (1998). Fishery Management Report, vol. 32. Interstate Fishery Management Plan for Horseshoe Crab. 58pp.

Botton, M. L., \& Itow, T. (2009). The Effects of Water Quality on Horseshoe Crab Embryos and Larvae. In J. T. Tanacredi, M. L. Botton, and \& D. R. Smith (Eds.), Biology and Conservation of Horseshoe Crabs, (pp. 439-454). New York: Springer.

Botton, M. L., \& Shuster, C. N. (2004). Horseshoe Crabs in a Food Web: Who Eats Whom? In C. N. Shuster, R. B. Barlow \& H. J. Brockmann (Eds.), The American Horseshoe Crab (pp. 133-153). Cambridge: Harvard Press.

Botton, M. L., Loveland, R. E., \& Jacobsen, T. R. (1988). Beach erosion and geochemical factors: Influence on spawning success of horseshoe crabs (Limulus polyphemus) in Delaware Bay. Marine Biology, 99(3), 325-332. http://dx.doi.org/10.1007/BF02112124

Briggs, D. (1977). Sources and methods in geography: sediments.

Brockmann, H. J. (1996). Satellite male groups in horseshoe crabs. Limulus Polyphemus. Ethology, 102, 1-21. http://dx.doi.org/10.1111/j.1439-0310.1996.tb01099.x

Brockmann, H. J., \& Penn, D. (1992). Male mating tactics in the horseshoe crab. Limulus Polyphemus. Animal Behaviour, 44, 653-665. http://dx.doi.org/10.1016/S0003-3472(05)80293-3 
Chatterji, A. (1994). The horseshoe crab- A living fossil. A Project Swarajya Publication, Cuttack, India.

Chiu, H. M. C., \& Morton, B. (1999). The distribution of horseshoe crabs (Tachypleus tridentatus and Carcinoscorpius rotundicauda) in Hong Kong. Asian Marine Biology, 16, 185-194.

Chiu, H. M. C., \& Morton, B. (2003). The morphological differentiation of two horseshoe crab species, Tachypleus tridentatus and Carcinoscorpius rotundicauda (Xiphosura), in Hong Kong with a regional Asian comparison. Journal of Natural History, 37(19), 2369-2382. http://dx.doi.org/10.1080/00222930210149753

Cohen, J. A., \& Brockmann, H. J. (1983). Breeding activity and mate selection in the horseshoe crab, Limulus polyphemus. Bulletin of Marine Science, 33, 274-281.

Ehlinger, G. S. \& Tankersley. R. A. (2003). Larval hatching in the horseshoe crab, Limulus polyphemus facilitation by environmental cues. Journal of Experimeental Marine Biology and Ecology. 292 (2), 199-212. http://dx.doi.org/10.1016/S0022-0981(03)00180-1

Ehlinger, G. S., \& Tankersley, R. A. (2004). Survival and development of horseshoe crab (Limulus polyphemus) embryos and larvae in hypersaline conditions. Biological Bulletin, 206, 87-94. http://dx.doi.org/10.2307/1543539

Ellingsen, K. E. (2002). Soft-sediment benthic biodiversity on the continental shelf in relation to environmental variability. Marine ecology Progress Series, 232, 15-27. http://dx.doi.org/10.3354/meps232015

Gretchen, S. E., \& Richard, A. T. (2006). Endogenous rhythms and entrainment cues of larval activity in the horseshoe crab Limulus polyphemus. Journal of Experimental Marine Biology and Ecology, 337, 205-214. http://dx.doi.org/10.1016/j.jembe.2006.06.035

Incera, M., Cividanes, S. P., Lastra, \& López, J. (2003). Temporal and spatial variability of sedimentary organic matter in sandy beaches on the northwest coast of the Iberian Peninsula. Estuarine, Coastal and Shelf Science, 58 (supplement), 55-61. http://dx.doi.org/10.1016/S0272-7714(03)00040-4

Jackson, N. L., Smith, D. R., Tiyarattanachai, R., \& Nordstrom, K. F. (2007). Evaluation of a small beach nourishment project to enhance habitat suitability for horseshoe crabs. Geomorphology, 89(1-2), 172-185. http://dx.doi.org/10.1016/j.geomorph.2006.07.017

Jegla, T. C., \& Costlow, J. D. (1982). Temperature and salinity effects on developmental and early posthatch stages of Limulus. Proceedings in Clinical and Biological Research, 81, 103-113.

John, B. A., Jalal, K. C. A., Kamaruzzaman, Y. B., \& Zaleha, K. (2010). Mechanism in the clot formation of horseshoe crab blood during bacterial endotoxin invasion. Journal of Applied science, 10(17), 1930-1936.

John, B. A., Kamaruzzaman, B. Y. Jalal, K. C. A., \& Zaleha. K. (2011). Hydrology of the horseshoe crab nesting grounds at Pahang coast, Malaysia. Oriental Journal of Chemistry, 27 (4), 1475-1483.

Kamaruzzaman, B. Y., Akbar John, B., Aqilah Megat, M. H., \& Zaleha, K. (2011b). Bioaccumulation of heavy metals in Horseshoe crabs (Tachypleus gigas) from Pekan, Pahang, Malaysia. Research Journal of Environmental Toxicology, 5 (3), 222-228. http://dx.doi.org/10.3923/rjet.2011.222.228

Kamaruzzaman, B. Y., Akbar John, B., Jalal, K. C. A., \& Zaleha, K. (2011a). Molecular Phylogeny of Horseshoe Crab. Asian Journal of Biotechnology. 3(3), 302-309. http://dx.doi.org/10.3923/ajbkr.2011.302.309

Lenore, S., Clescerl, Arnold, E., Greenberg, Andrew, D. E. (1999). Standard Methods for Examination of Water \& Wastewater (20th ed.). Washington, DC: American Public Health Association. ISBN 0-87553-235-7.

Mikkelsen, T. (1988). The secret in the blue blood. Scientific Press, Beijing, China. pp 1-123.

Penn, D., \& Brockmann, H. J. (1994). Nest-site selection in the horseshoe crab, Limulus polyphemus. Biological Bulletin, 187, 373-384. http://dx.doi.org/10.2307/1542294

Shuster, C. N. (2004). A Blue Blood: The Circulatory System. In: The American Horseshoe Crab, (1st ed.): Harvard University Press, USA.

Shuster, C. N., Barlow, R. B., \& Brockmann, H. J. (2003). The American horseshoe crab. Harvard University Press.

Shuster, Jr. C. N. (1982). A pictorial review of the natural history and ecology of the horseshoe crab, Limulus polyphemus, with reference to other Limulidae. In: Bonaventura, J., Bonaventura, C., Tesh, S. (Eds.), Physiology and Biology of Horseshoe Crabs: Studies on Normal and Environmentally Stressed Animals. Alan R. Liss, New York. pp. 1-52. 
Sokoloff, A. (1978). Observations on populations of the horseshoe crab Limulus polyphemus (=Xiphosura). Researches on Population Ecology, 19(2), 222-236. http://dx.doi.org/10.1007/BF02518829

Tanacredi, J. T., Botton, M. L., \& Smith, D. (2009). Biology and Conservation of Horseshoe Crabs: Springer. ISBN: 978-0-387-89958-9. http://dx.doi.org/10.1007/978-0-387-89959-6

Wentworth, E. Y., Mazda, Y., \& Ridd, P. (1992). Mangrove hydrodynamics. In tropical mangrove ecosystems. In A. I. Robertson, and Alongi, D.M. (Ed.), (pp. 436-462). Washington D.C.: American Geophysical Union. ISSN: 0733-9569

Wyse, G. A. (1971). Receptor organization and function in Limulus chelae. Zeitschrift für Vergleichende Physiologie, 73, 249-273. http://dx.doi.org/10.1007/BF00297675

Zaleha, K., Hazwani, I., Siti Hamidah, H., Kamaruzzaman, B. Y., \& Jalal, K. C. A. (2011). Effect of salinity on egg hatching and early larvae of horseshoe crab Tachypleus gigas (Muller 1785) in laboratory culture. Journal of applied sciences, 11(14): 2620-2626. http://scialert.net/abstract/doi=jas.2011.2620.2626

Zaleha, K., Kamaruzzaman, B. Y., John, B. A., \& Ong, M. C. (2010). Cd, Cu and Pb Concentration Levels in Horseshoe Crab Nesting Grounds of Pahang Coast, Malaysia. Journal of Biological Sciences, 10(8), 790-794. http://dx.doi.org/10.3923/jbs.2010.790.794

Table 1. Number of horseshoe crab nests found in the nesting grounds (Balok and Pekan) during the sampling months and the number of fertilized eggs, pretrilobite and trilobite larvae observed in each nests

\begin{tabular}{|c|c|c|c|c|c|c|c|c|}
\hline $\begin{array}{l}\text { Mont } \\
\text { hs }\end{array}$ & $\begin{array}{l}\text { Locati } \\
\text { ons }\end{array}$ & $\begin{array}{c}\text { Nest } \\
\text { Number }\end{array}$ & $\begin{array}{l}\text { Number } \\
\text { of Eggs }\end{array}$ & $\begin{array}{c}\text { Number of } \\
\text { Pretrilobite } \\
\text { larvae }\end{array}$ & $\begin{array}{c}\text { Number of } \\
\text { Hatch trilobite } \\
\text { larvae }\end{array}$ & Total & $\begin{array}{c}\text { Nest } \\
\text { width } \\
\text { (cm) }\end{array}$ & $\begin{array}{c}\text { Nest } \\
\text { depth } \\
\text { (cm) }\end{array}$ \\
\hline \multirow{5}{*}{$\begin{array}{l}\text { Septe } \\
\text { mber }\end{array}$} & Pekan & 1 & 0 & 350 & 0 & 350 & 20 & 11 \\
\hline & \multirow{4}{*}{ Balok } & 1 & 376 & 0 & 0 & 376 & 17 & 12 \\
\hline & & 2 & 407 & 0 & 0 & 407 & 19 & 12 \\
\hline & & 3 & 400 & 0 & 0 & 400 & 26 & 12 \\
\hline & & 4 & 367 & 0 & 0 & 367 & 24 & 15 \\
\hline \multirow{8}{*}{$\begin{array}{l}\text { Octob } \\
\text { er }\end{array}$} & \multirow{7}{*}{ Pekan } & 1 & 87 & 28 & 14 & 129 & 23 & 12 \\
\hline & & 2 & 216 & 0 & 0 & 216 & 17 & 12 \\
\hline & & 3 & 164 & 0 & 0 & 164 & 20 & 8 \\
\hline & & 4 & 191 & 0 & 0 & 191 & 9 & 9 \\
\hline & & 5 & 69 & 0 & 0 & 69 & 28 & 10 \\
\hline & & 6 & 331 & 0 & 0 & 331 & 24 & 9 \\
\hline & & 7 & 44 & 0 & 0 & 44 & 27 & 5 \\
\hline & Balok & 0 & 0 & 0 & 0 & 0 & 0 & 0 \\
\hline \multirow{12}{*}{$\begin{array}{l}\text { Nove } \\
\text { mber }\end{array}$} & \multirow{11}{*}{ Pekan } & 1 & 123 & 121 & 3 & 247 & 15 & 9 \\
\hline & & 2 & 326 & 0 & 0 & 326 & 25 & 11 \\
\hline & & 3 & 156 & 0 & 0 & 156 & 28 & 15 \\
\hline & & 4 & 0 & 0 & 391 & 391 & 24 & 10 \\
\hline & & 5 & 1 & 0 & 51 & 52 & 18 & 9 \\
\hline & & 6 & 1 & 0 & 1 & 2 & 18 & 10 \\
\hline & & 7 & 105 & 0 & 0 & 105 & 23 & 11 \\
\hline & & 8 & 203 & 0 & 0 & 203 & 23 & 13 \\
\hline & & 9 & 0 & 22 & 109 & 131 & 23 & 10 \\
\hline & & 10 & 0 & 0 & 9 & 9 & 18 & 10 \\
\hline & & 11 & 300 & 0 & 9 & 309 & 8 & 9 \\
\hline & Balok & 0 & 0 & 0 & 0 & 0 & 0 & 0 \\
\hline \multirow{4}{*}{$\begin{array}{l}\text { Dece } \\
\text { mber }\end{array}$} & \multirow{3}{*}{ Pekan } & 1 & 12 & 0 & 1 & 13 & 11 & 11 \\
\hline & & 2 & 12 & 7 & 288 & 307 & 15 & 11 \\
\hline & & 3 & 16 & 7 & 78 & 101 & 16 & 13 \\
\hline & Balok & 0 & 0 & 0 & 0 & 0 & 0 & 0 \\
\hline
\end{tabular}


Table 2. Variation in the major hydrographic parameters observed at the surface waters of nursery sites

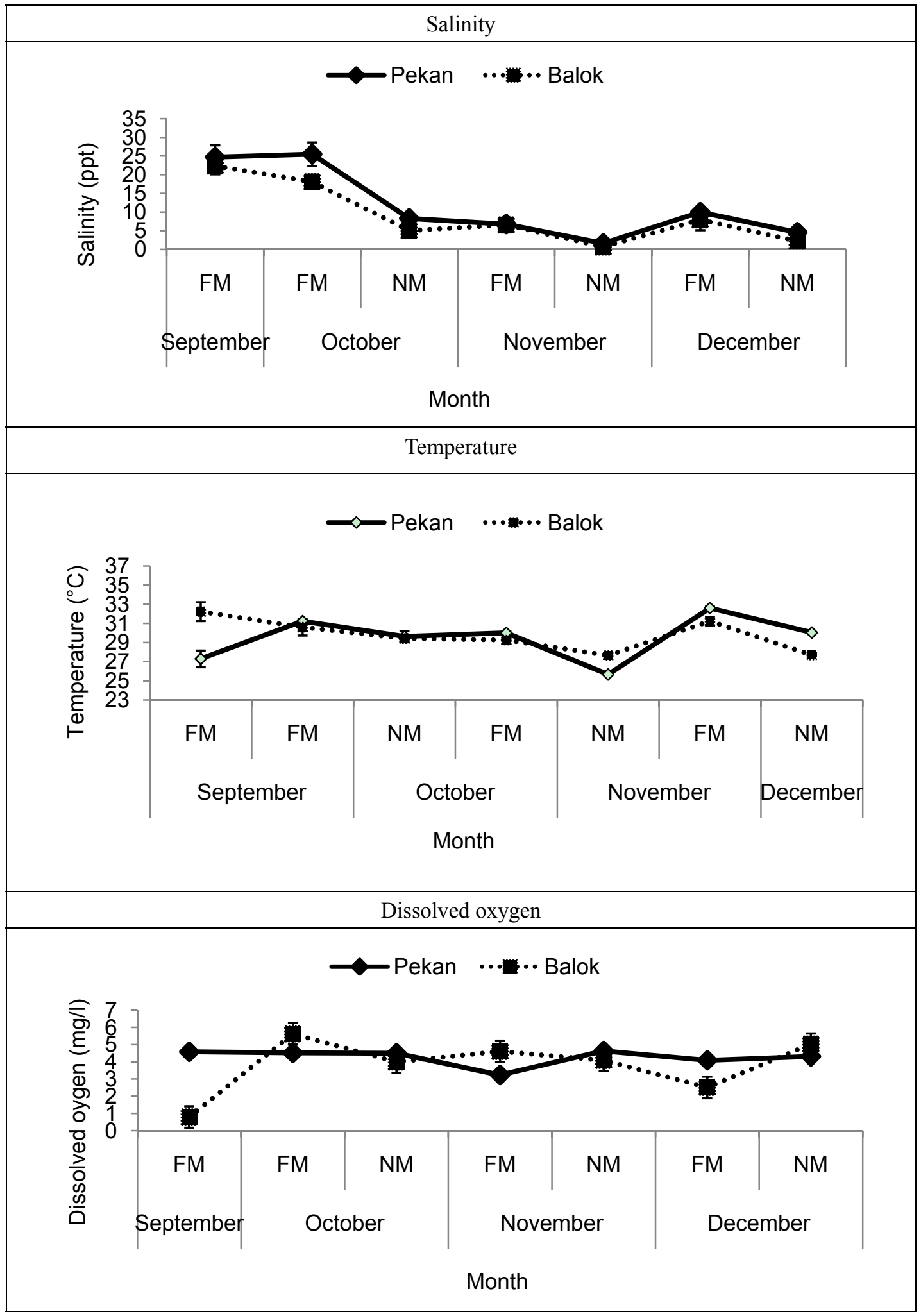


Table 3. Summary of surface sediment characteristics of the horseshoe crab nursery beaches during monsoon season. Values are presented in means

\begin{tabular}{|c|c|c|c|c|c|}
\hline \multirow{2}{*}{ Months } & \multirow{2}{*}{ Parameters } & \multicolumn{2}{|c|}{ Pekan } & \multicolumn{2}{|c|}{ Balok } \\
\hline & & NM & FM & NM & FM \\
\hline \multirow{3}{*}{ September } & $\operatorname{Mean}(\varnothing)$ & - & 0.77 & - & 1.95 \\
\hline & $\begin{array}{l}\text { Sediment Sorting } \\
\text { value }\end{array}$ & - & 1.03 & - & 1.02 \\
\hline & TOM (\%) & - & 0.04 & - & 0.30 \\
\hline \multirow{3}{*}{ October } & Mean $(\varnothing)$ & 0.59 & 0.74 & 2.24 & 1.86 \\
\hline & $\begin{array}{l}\text { Sediment Sorting } \\
\text { value }\end{array}$ & 1.04 & 0.88 & 0.68 & 1.1 \\
\hline & TOM (\%) & 0.36 & 0.31 & 0.74 & 0.64 \\
\hline \multirow{3}{*}{ November } & $\operatorname{Mean}(\varnothing)$ & 0.74 & 0.8 & 2.48 & 2.32 \\
\hline & $\begin{array}{l}\text { Sediment Sorting } \\
\text { value }\end{array}$ & 0.83 & 0.82 & 0.62 & 0.8 \\
\hline & TOM (\%) & 0.50 & 0.44 & 0.66 & 0.70 \\
\hline \multirow{3}{*}{ December } & Mean(Ø) & 0.67 & 0.38 & 2.43 & 2.57 \\
\hline & $\begin{array}{l}\text { Sediment Sorting } \\
\text { value }\end{array}$ & 0.93 & 0.86 & 0.46 & 0.54 \\
\hline & TOM (\%) & 0.34 & 0.36 & 0.76 & 0.68 \\
\hline
\end{tabular}

FM - full moon period; NM - New-moon period; TOM - Total Organic Matter.

Table 4. Summary of Pearson's Correlation Analysis on shows the influence of various parameters over the number of horseshoe crab nests and egg counts in Balok and Pekan nursery grounds respectively

\begin{tabular}{|c|c|c|c|c|c|}
\hline \multirow{2}{*}{ Parameters } & \multirow{2}{*}{$\begin{array}{l}\text { Sampling } \\
\text { stations }\end{array}$} & \multicolumn{2}{|c|}{$\begin{array}{c}\text { Number of horseshoe crab } \\
\text { nests }\end{array}$} & \multicolumn{2}{|c|}{ Eggs count } \\
\hline & & $\begin{array}{l}\text { Correlation } \\
\text { value }\end{array}$ & $\begin{array}{l}\text { Significant } \\
\text { value }(\mathrm{P})\end{array}$ & $\begin{array}{l}\text { Correlation } \\
\text { value }\end{array}$ & $\begin{array}{l}\text { Significant } \\
\text { value }(\mathrm{P})\end{array}$ \\
\hline \multirow{2}{*}{ Salinity } & Balok & 0.723 & 0.066 & 0.824 & 0.074 \\
\hline & Pekan & -0.085 & 0.857 & -0.091 & 0.762 \\
\hline \multirow{2}{*}{ Temperature } & Balok & 0.637 & 0.124 & 0.591 & 0.212 \\
\hline & Pekan & -0.149 & 0.749 & -0.258 & 0.675 \\
\hline \multirow{2}{*}{ Dissolved oxygen } & Balok & $0.822^{*}$ & 0.023 & $0.798^{*}$ & 0.025 \\
\hline & Pekan & -0.31 & 0.511 & 0.437 & 0.598 \\
\hline \multirow{2}{*}{ Mean sediment size } & Balok & -0.516 & 0.236 & -0.487 & 0.312 \\
\hline & Pekan & 0.519 & 0.233 & 0.453 & 0.345 \\
\hline \multirow{2}{*}{ Sediment sorting value } & Balok & 0.512 & 0.251 & 0.623 & 0.211 \\
\hline & Pekan & -0.579 & 0.173 & -0.654 & 0.468 \\
\hline \multirow{2}{*}{ Total organic content } & Balok & $-0.954^{*}$ & 0.001 & $-0.948^{*}$ & 0.001 \\
\hline & Pekan & 0.482 & 0.301 & 0.657 & 0.575 \\
\hline
\end{tabular}

${ }^{*}$ Correlation significant at the 0.05 level (2-tailed). 


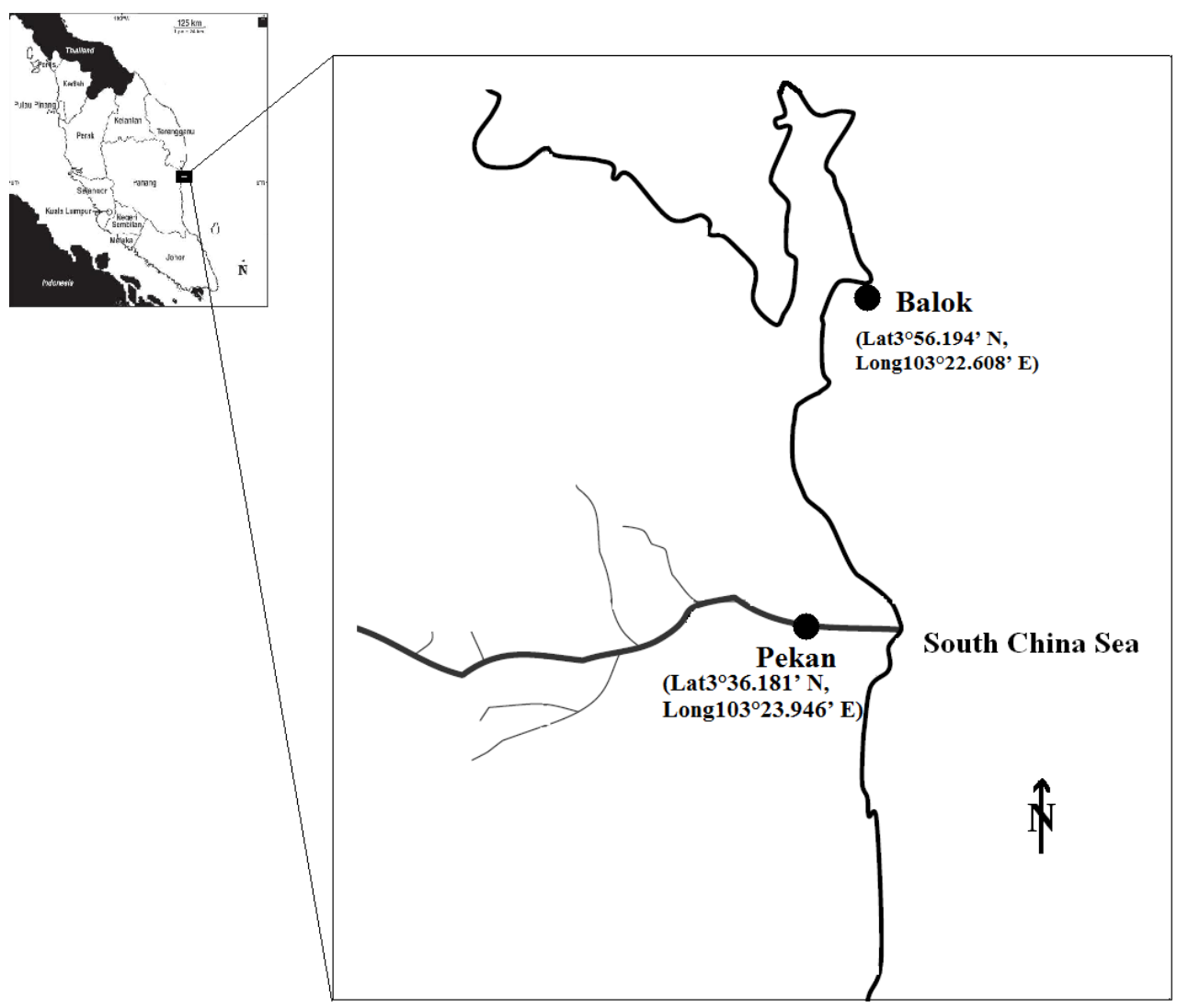

Figure 1. Location of the sampling sites along the East coast of Peninsular Malaysia 